\author{
RenAta BednARZ-GRZYbeK \\ Uniwersytet Marii Curie-Skłodowskiej \\ $w$ Lublinie \\ IZABELA KRASIŃSKA \\ Uniwersytet Jana Kochanowskiego \\ w Kielcach
}

\title{
EDUKACJA ZDROWOTNA I SEKSUALNA NA ŁAMACH „ŚWIATA PŁCIOWEGO” (1905-1906)
}

\begin{abstract}
AвSTRACT. Bednarz-Grzybek Renata, Krasińska Izabela, Edukacja zdrowotna i seksualna na łamach „Świata Ptciowego" (1905-1906) [The Health and Sexual Education in the Pages of "Sexual World" (1905-1906)]. Studia Edukacyjne nr 50, 2018, Poznań 2018, pp. 369-385. Adam Mickiewicz University Press. ISSN 1233-6688. DOI: $10.14746 /$ se.2018.50.24
\end{abstract}

Health education is related to the health promotion. This is a process aimed to shaping people's habits of taking care of their and other people's health. The sexual education can be considered as one of the health education departments. The article attempts to show the answer to the question how in the pages of the "Sexual World" coming out in Lviv in 1905-1906, how to prevent and cope during the illness was taught, and suggested where to look for the medical care, especially in the case of venereal diseases, which are often side effects of prostitution.

Key words: health education, sex education, "Sexual World"

Edukacja zdrowotna związana jest z promocją zdrowia, do zadań której należy „zapewnienie warunków umożliwiających podejmowanie decyzji ukierunkowanych na zdrowie"1. Jest procesem mającym na celu ukształtowanie u ludzi nawyków dbania o zdrowie swoje i innych osób. Uzyskane w tym zakresie kompetencje mogą być przydatne w podejmowaniu przez człowieka właściwych wyborów dotyczących jakości swego życia. Posiadają również aspekt profilaktyczny w przypadku różnych zagrożeń chorobowych. Eduka-

${ }^{1}$ Czym jest edukacja zdrowotna?, http://edukacja.pomocnie.com.pl/czym-jest-edukacja-zdrowotna/ [dostęp: 02.11.2016]. 
cja zdrowotna pomaga wypracować nawyki, dzięki którym można świadomie dbać o higienę, zapobiegając $w$ ten sposób powstawaniu i rozwojowi różnych chorób. Często bywa utożsamiana z takimi pojęciami, jak: pedagogika zdrowia, oświata zdrowotna, kultura zdrowotna, a w obecnych czasach coraz rzadziej oświata sanitarna. Określenia te są stosunkowo nowe, bo pochodzą z lat 50.-80. ubiegłego wieku. $W$ ostatnich latach pojawił się jeszcze jeden jej synonim, czyli nauka o zdrowiu. Wcześniej, bo w końcu XIX i pierwszej połowie XX stulecia edukację zdrowotną określano mianem działalności higieniczno-wychowawczej, prowadzonej przeważnie przez szkołę ${ }^{2}$.

Za jeden z działów edukacji zdrowotnej można uznać edukację seksualną (promocję zdrowia seksualnego) związaną między innymi z płodnością człowieka, zaburzeniami w życiu płciowym, czy chorobami wenerycznymi. Prostytucję i pornografię zalicza się do zjawisk społecznych związanych ze sferą seksualną.

Celem artykułu jest próba ukazania odpowiedzi na pytanie, $\mathrm{w}$ jaki sposób wychodzący we Lwowie w latach 1905-1906 „Świat Płciowy" poruszał problem zapobiegania i radzenia sobie $\mathrm{w}$ trakcie choroby oraz sugerował gdzie szukać opieki medycznej, zwłaszcza w przypadku zarażenia chorobami wenerycznymi, będącymi niejednokrotnie ubocznymi skutkami prostytucji. Periodyk radził również, jak należy zwalczać prostytucję i zapobiegać jej powstawaniu, na jakie kwestie zwracać uwagę zawierając związek małżeński i jak rozmawiać z młodzieżą o sprawach płciowych oraz dewiacjach seksualnych.

Najwcześniejsze informacje o prostytucji w Polsce pochodzą z XIV-XV wieku, choć niewątpliwie istniała już wcześniej. W połowie XV stulecia domy publiczne znajdujące się wówczas pod opieką kata miejskiego legalnie funkcjonowały na przykład w Krakowie, Busku, Pyzdrach, czy Pobiedziskach. Od najdawniejszych czasów na prostytutki nakładane były surowe kary. Wystawiano je między innymi nago w klatce na widok publiczny, poddawano chłoście, okaleczeniom ciała, wypędzano z miast; w późniejszym okresie (XVIII-XIX w.) kierowano do specjalnych domów pracy czy domów poprawy. Istotne zmiany statusu prostytucji dokonały się na przełomie XVIII i XIX stulecia w Prusach, a w 1802 roku wprowadzono je w Warszawie. Starano się kontrolować ją poprzez wdrożenie tak zwanego systemu reglamentacyjnego, który pojawił się w Europie w czasach Napoleona Bonapartego. Z uwagi na szerzące się choroby przenoszone drogą płciową zalecano umieszczanie prostytutek $\mathrm{w}$ domach publicznych, nad którymi kontrolę przejęły służby policyjne oraz sanitarne. Realizacja wymienionych założeń prowadziła do

2 Tamże; B. Woynarowska, Edukacja zdrowotna. Podręcznik akademicki, Warszawa 2013, s. $98-$ 101; I. Krasińska, Edukacja zdrowotna żeńskiej stużby domowej na łamach "Przyjaciela Stug" (18971918) (w druku). 
rejestracji kobiet uprawiających nierząd, którym policja wydawała prawo wykonywania zajęcia, nakładając na nie obowiązek przymusowych badań lekarskich oraz opodatkowanie domów publicznych. Trudniące się prostytucją musiały informować władze policyjne o zmianie miejsca pobytu, choć często zabierano im dowody tożsamości, co uniemożliwiało zmianę miejsca zamieszkania. Skreślenie $\mathrm{z}$ rejestru możliwe było $\mathrm{w}$ przypadku zawarcia związku małżeńskiego, podjęcia innej pracy, choroby oraz na żądanie rodziców bądź krewnych. Prostytucją mogły się trudnić dziewczęta od 16. roku życia, ale uprawiały ją również i młodsze, natomiast kobiety zamężne tylko za zgodą męża. Surowe kary nakładane były na tajne prostytutki, kuplerki, stręczycieli oraz handlarzy żywym towarem. Choć system reglamentacyjny był obowiązkowy, to jak czas pokazał, na ulicach europejskich czy polskich miast kwitła tak zwana prostytucja swobodna. Wiele kobiet, nawet kosztem zatrzymania przez policję i surowych kar, nadal wolało uprawiać ją $\mathrm{w}$ tradycyjny sposób. Policja zobowiązana była śledzić kobiety uprawiające nielegalny nierząd. Liczba klientów przypadających na jedną prostytutkę w skali dnia sięgała nawet 15, co znajdowało odzwierciedlenie w wypłacie ${ }^{3}$.

Prostytutki stanowiły grupę dość spolaryzowaną i wykazującą się pomysłowością w pozyskiwaniu klientów. Najniżej w hierarchii stały ulicznice świadczące usługi głównie żebrakom czy włóczęgom, nieraz w miejscach publicznych, na przykład w parkach, za kieliszek wódki lub coś do jedzenia. Bardziej wymagające poznawały klientów na balach oraz w luksusowych lokalach gastronomicznych (kawiarniach, restauracjach). W Warszawie istniał nawet, oceniany pozytywnie, specjalny zakład schadzek dla szukających przelotnej znajomości; zainteresowany wiedział, gdzie ma się udać. Najwyżej stały kokoty, czyli damy do towarzystwa znane też jako metresy lub utrzymanki, obcujące z bogatymi i wymagającymi klientami. Kobiety takie nie były tylko kochankami, ale niejednokrotnie powiernicami swych klientów. Oczekiwano od nich wdzięku, elegancji, salonowych manier, dyskrecji i wierności. Miały pełną swobodę w wyborze klientów ${ }^{4}$.

Na przełomie XIX i XX wieku na ziemiach polskich zaczęto zakładać organizacje, do zadań których należało: przeciwdziałanie szerzącej się prostytucji, otaczanie opieką kobiet i dziewcząt, informowanie o sposobach działań stręczycieli, zwalczanie chorób wenerycznych, czy upowszechnianie zasad

${ }^{3}$ J. Sikorska-Kulesza, Zło tolerowane. Prostytucja w Królestwie Polskim w XIX wieku, Warszawa 2004, s. 29-45; M. Krawczyńska, Kuplerka, sutener i stręczycielstwo. Regulacja polskiego prawa, Prawo i Płeć, 2006, 8, s. 11-12; A. Bołdyrew, Społeczeństwo Królestwa Polskiego wobec patologii społecznych w latach 1864-1914, Łódź 2016, s. 145-146; M. Baczkowski, Prostytucja w Krakowie na przetomie XIX i XX w., Studia Historyczne, 2000, 4, s. 593-594; P. Gołdyn, Pogarda dla zawodu, litość dla człowieka. Społeczno-edukacyjne formy działalności wobec kobiet zagrożonych prostytucją w Polsce (1918-1939), Kalisz 2013, s. 28.

${ }^{4}$ A. Lisak, Miłość, kobieta i małżeństwo w XIX wieku, Warszawa 2009, s. 268-269. 
abolicjonizmu. Prowadziły one działalność kulturalną, towarzyską i oświatową, pomagały byłym prostytutkom w znalezieniu pracy, przyuczały ich do nowych zawodów ${ }^{5}$.

Zagadnienia seksualne podejmowane były również na szpaltach prasy. Donosiły o nich pisma pedagogiczne, medyczne, higieniczne, abstynenckie, religijne, czy społeczne. W początkach XX wieku na rynku prasowo-wydawniczym Galicji pojawiły się dwa pisma poświęcone tym problemom. Należała do nich "Czystość" (1905-1909)6 oraz stanowiący przedmiot niniejszego artykułu "Świat Płciowy”.

Periodyk ten ukazywał się z częstotliwością miesięczną od maja 1905 do lutego 1906 roku i jak głosił podtytuł, miał charakter popularny, a nie naukowy, jaki przypisywano abstynenckiej „Czystości”. Pismo wychodziło we Lwowie, a siedziba redakcji znajdowała się przy ulicy Ochronek 10. Pojedynczy numer kosztował koronę, abonament półroczny - 5 koron, a roczny 10 koron. Czasopismo drukowano u Zygmunta Hałacińskiego. Objętość numeru przekraczała 50 stron. Redaktorem odpowiedzialnym i wydawcą czasopisma był Juliusz Seidler, zaś naczelnym Antoni Stanisław Berger (18421907), podpisujący się jako Antoni Roicki. Urodzony w Hrubieszowie, po ukończeniu gimnazjum poświęcił się farmacji. W roku 1862 zapisał się na Wydział Lekarski Szkoły Głównej Warszawskiej, a następnie przeniósł na studia medyczne do Krakowa, które ukończył w 1869 roku. Po odbyciu wycieczki naukowej do Niemiec, dalsze życie prywatne i zawodowe związał ze Lwowem. Zatrudniony był między innymi w szpitalu głównym, początkowo na oddziale psychiatrycznym, a później położniczym7 ${ }^{7}$.

Choć „Świat Płciowy” był redagowany przez lekarza, to ówczesne środowisko medyczne - jak pisał Marek Babik - klasyfikowało pismo jako pornograficzne. Zawarte w nim treści dotykały bowiem takich problemów, jak aktywność seksualna młodzieży, a ich forma mogła budzić podejrzenia, że redakcji bardziej chodziło o czytelnika przyciąganego sensacją i „biologicznymi szczegółami współżycia seksualnego", niż o poziom merytoryczny zamieszczanych tekstów. Pismo opowiadało się za zalegalizowaniem prostytucji w postaci prawnych uregulowań, co niekiedy oburzało autorów piszących do "Czystości" ${ }^{\text {. }}$. Zarzucali temu periodykowi propagowanie tak zwanej umiarkowanej rozpusty i domagania się prawnego uregulowania prostytucji.

5 A. Bołdyrew, Społeczne inicjatywy na rzecz walki z patologiami w Królestwie Polskim na przełomie XIX i XX wieku, Studia Gdańskie, 2012, 31, s. 250-251.

${ }^{6}$ Na temat tego pisma powstała m.in. monografia, zob. szerzej: J. Franke, "Czystość" (19051909) Augustyna Wróblewskiego albo iluzja etycznej krucjaty, Warszawa 2013.

7 S. Kośmiński, Słownik lekarzów polskich, Warszawa 1888, s. 25; J. Jarowiecki, Prasa lwowska w latach 1864-1918. Bibliografia, Kraków 2002, s. 406.

8 M. Babik, Polskie koncepcje wychowania seksualnego w latach 1900-1939, Kraków 2010, s. $62,119$. 
Nazywali miesięcznik „kwiatem zepsucia”, „pikantną lekturą”, czasopismem pornograficznym, a przy tym „siejącym zgniliznę" $\mathrm{i}$ „wyrabiającym lubieżną wyobraźnię". Uważano, że artykuły zamieszczane na łamach „Świata Płciowego" są tylko z pozoru naukowe, a w rzeczywistości pełne rażących błędów rzeczowych". Twórcy "Czystości” negatywnie wypowiadali się również na temat zamieszczanych w "Świecie Płciowym" anonsów:

Ogromny szereg reklam i anonsów o „najnowszych paryskich najpewniejszych i najwygodniejszych, antyseptycznych, rozpuszczalnych i gumowych środkach ochronnych dla panów i pań", między którymi widnieje i powtarzająca się w każdym numerze reklama redaktora, który "leczy najnowszą metodą", dają wyraźne świadectwo o tym, na co obliczone jest to wydawnictwo ${ }^{10}$.

Teksty zamieszczane na szpaltach „Świata Płciowego" dość często podpisane były imieniem i nazwiskiem, pseudonimem, czy kryptonimem autora. Obok tekstów redaktora Antoniego Bergera publikowano też artykuły między innymi: Leopolda Bronisława Wołowicza (1883-1931), filozofa oraz nauczyciela gimnazjalnego we Lwowie i Brodach, czy Maksymiliana Landau (1870-1927), adwokata oraz działacza socjalistycznego.

Dla twórców „Świata Płciowego" poważnym problemem natury moralno-zdrowotnej była prostytucja, a ponieważ miesięcznik ukazywał się we Lwowie, zwracano głównie uwagę na nierząd szerzący się w tym mieście. Informowano też czytelników o historii tego niepożądanego zjawiska społecznego. Początków prostytucji doszukiwano się w starożytności, znana również była w Biblii. Lwów początku XX wieku nie odbiegał zasadniczo w tym zakresie od normy, gdyż obok „jawnogrzesznic” świadczyły usługi „dyskretne nierządnice, wymykające się spod rachuby"11.

Przyczyn prostytucji upatrywano w złym wychowaniu, nędzy i braku perspektyw na znalezienie innej pracy. Znane były również przypadki, że to rodzice namawiali córki do nierządu, a nawet dopuszczali się stręczycielstwa, jak czyniła to na przykład praczka ze Szczecina Karolina Schrocker. Za dość problematyczny powód prostytucji redakcja pisma uważała nadmierny popęd seksualny ${ }^{12}$.

Donoszono czytelnikom, że w 1904 roku we Lwowie „najstarszy zawód świata" wykonywało zdaniem policji aż 20000 kobiet w wieku 15-50 lat, z których tylko 488 było notowanych, a 119 pozostawało pod stałym dozo-

9 "Świat Płciowy", "Czystość" 1906, nr 13-14, s. 171-172; "Świat Płciowy”. (Ciag dalszy), "Czystość" 1906, nr 22-23, s. 318-319.

${ }_{10}$ "Świat Ptciowy", s. 172.

${ }^{11}$ Dr. Wł. S-i, Prostytucja. Ze szczególnym uwzględnieniem stosunków lwowskich I, „Świat Płciowy" 1905, maj, s. 30-36.

12 Prostytucja we Lwowie II, „Świat Płciowy” 1906, luty, s. 28-30; Drobiazgi. Matka stręczycielka córek, „Świat Płciowy” 1906, styczeń, s. 48. 
rem policyjnym. Grupa znanych policji 366 prostytutek była katoliczkami, pozostałe to Żydówki. Blisko $200 \mathrm{z}$ nich rekrutowało się spośród służących ${ }^{13}$.

Rozpatrując zjawisko prostytucji, redakcja miesięcznika miała na uwadze trzy jej rodzaje: prostytucję kontrolowaną przez policję; wymykającą się spod tej kontroli, ale traktowaną jako źródło utrzymania i wreszcie prostytucję rozumianą jako rozpustę uprawianą celem zaspokojenia potrzeb seksualnych. W przypadku nierządu kontrolowanego, propagowanego przez „Świat Płciowy", prostytutki winny być ze względów sanitarnych zarejestrowane przez policję, posiadać książeczki zdrowia i poddawać się okresowym badaniom lekarskim. W większych miastach Galicji, liczących więcej niż 10000 mieszkańców i posiadających koszary wojskowe, obowiązywała wówczas policyjna instrukcja „nadzoru nad publicznymi nierządnicami”. W jej myśl policja winna stosować nadzór nie tylko nad prostytucją jawną, ale i tajną, a od 1 marca 1906 roku również nad nową jej kategorią, czyli tak zwaną prostytucją dyskretną, wprowadzoną we Lwowie jako pierwszym z miast monarchii austro-węgierskiej. Prostytutki z tej ostatniej grupy nie musiały wprawdzie mieć książeczek zdrowia, ale podlegały cotygodniowej „policyjno-sanitarnej rewizji", a w przypadku stwierdzenia u nich choroby wenerycznej musiały poddać się obowiązkowemu leczeniu szpitalnemu ${ }^{14}$. Redakcja „Świata Płciowego", powołując się na opinię krajowego inspektora sanitarnego lekarza Józefa Barzyckiego (1841-1908), narzekała jednak na warunki, w jakich obywały się te badania (rewizje), a zwłaszcza na nieodpowiednie pomieszczenia; na przykład w Drohobyczu, gdzie okno w pokoju usytuowanym na parterze wychodziło wprost na ulicę, a w Trembowli na dziedziniec szkolny ${ }^{15}$.

Jak już wspomniano, częstym następstwem prostytucji były choroby weneryczne. Zdaniem lekarzy współpracujących ze „Światem Płciowym”, przyczyn zachorowań prostytutek na choroby intymne należało doszukiwać się w lekkomyślności nie dbających o swoje i cudze zdrowie klientów, którzy nie zastanawiali się nad tym, że „zarażona jawnogrzesznica, zanim zjawi się (...) przed lekarzem policyjnym, może (...) - gdy właśnie ma szczęście do gości - całym ich dziesiątkom jad strasznej choroby zaszczepić"16. Radzono więc, aby domy publiczne zakładać ustawowo, a badaniom lekarskim poddawać nie tylko prostytutki, ale również ich klientów, jak się to praktykowało na przykład w największych włoskich domach schadzek. Natomiast w amerykańskim stanie Kolorado istniał nakaz przymusowego używania prezerwa-

${ }^{13}$ Dr. Wł. S-i, Prostytucja, „Świat Płciowy” 1905, październik, s. 11-13; J. Bilewski, Stużące a prostytucja, "Świat Płciowy” 1905, październik, s. 33-39; Nierząd służby żeńskiej, „Świat Płciowy" 1905, wrzesień, s. 42; Prostytucja we Lwowie I, „Świat Płciowy" 1906, styczeń, s. 35.

${ }^{14}$ Prostytucja we Lwowie II, s. 20-26.

${ }^{15}$ Nadzór nad prostytucją u nas, „Świat Płciowy” 1905, grudzień, s. 15.

${ }^{16}$ Dr. Wł. S-i, Prostytucja, s. 14. 
tyw przez klientów tamtejszych domów publicznych. Zastanawiano się także nad potrzebą stworzenia dla prostytutek kas chorych ${ }^{17}$.

Twórcy miesięcznika opisywali najczęściej występujące choroby weneryczne oraz radzili, a przez to edukowali czytelników, jak sobie z nim radzić i co robić, by się nimi nie zarazić. Do schorzeń przenoszonych drogą płciową miesięcznik zaliczał: rzeżączkę (tryper), kiłę (syfilis) oraz wrzód miękki (szankier), funkcjonujący obecnie pod nazwą wrzodu wenerycznego.

Pierwsza z tych intymnych chorób, czyli rzeżączka, stanowiła ropny wypływ z cewki moczowej, który podczas stosunku z zarażoną partnerką przenosił się na partnera. Było to schorzenie bardzo poważne w skutkach i mogło prowadzić do zapalenia pęcherza moczowego, gruczołu krokowego, gruczołów limfatycznych i pachwinowych, a nawet zapalenia nerek, stawów i osierdzia. Nieleczona rzeżączka wpływała też na bezpłodność. Lekarz Adam Szulisławski (1865-1911), specjalista w zakresie okulistyki, był nawet zdania, że choroba ta mogła być przenoszona przez matki na noworodków i wywołać u nich zapalenie oczu. Leczenie było długotrwałe, a pacjenta obowiązywał między innymi zakaz picia alkoholu oraz spożywania ostrych przypraw i kwaśnych dań. Nie należało też w trakcie kuracji biegać, gimnastykować się i jeździć konno ${ }^{18}$.

Kiła wywoływana była przez bakterię zwaną krętkiem bladym, która przedostawała się przez błony śluzowe lub uszkodzoną skórę. Charakteryzowała ją początkowo bezbolesna i nie swędząca, a więc łatwa do przeoczenia wysypka, przechodząca z czasem w owrzodzenie widoczne w okolicach narządów płciowych, ale również na języku, ustach, czy w gardle. Nieleczony syfilis mógł doprowadzić między innymi do utraty włosów, a nawet ubytków w podniebieniu. Chorujący na syfilis mieli całkowity zakaz współżycia seksualnego, bardziej odpowiedzialni zawierali związki małżeńskie za zgodą lekarza, ale dopiero po 3-5 latach od momentu rozpoczęcia kuracji ${ }^{19}$.

Ostatnią z omawianych na łamach "Świata Płciowego" chorób intymnych był tak zwany szankier, czyli wrzód weneryczny. Objawiał się ropiejącą, często też krwawiącą raną, umiejscowioną na narządach płciowych. Zaniedbanie choroby mogło na przykład doprowadzić do zapalenia pachwiny ${ }^{20}$.

Choroby weneryczne nie pozostawały bez wpływu nawet na ustrój nerwowy. Jak pokazały badania przeprowadzone przez węgierskiego lekarza

\footnotetext{
17 Tamże; Drobiazgi. Kasy chorych dla prostytutek, „Świat Płciowy” 1905, wrzesień, s. 51-52; Drobiazgi. Obowiazkowe prezerwatywy, "Świat Płciowy” 1905, listopad, s. 47.

${ }_{18}$ O zapobieganiu chorób wenerycznych, "Świat Płciowy" 1905, wrzesień, s. 44-45; Tryper, „Świat Płciowy” 1906, styczeń, s. 25-26; Drobiazgi. Tryprowe zapalenie oczu u noworodków, „Świat Płciowy” 1906, luty, s. 44; Prof. Dr Adam Szulistawski, „Lwowski Tygodnik Lekarski” 1911, nr 49, s. 652.

${ }^{19}$ O zapobieganiu chorób wenerycznych, s. 45, 47; A. Roicki, Syfilis i małżeństwo, „Świat Płciowy" 1905, grudzień, s. 8-10.

${ }^{20}$ O zapobieganiu chorób wenerycznych, s. 45.
} 
Vörösa, aż 90\% chorób psychicznych miało „swoje źródło w chorobach wenerycznych". Uczony starał się udowodnić, że następstwem choroby płciowej może być choroba umysłowa, w tym załamanie nerwowe, a nawet obłęd ${ }^{21}$.

Radzono czytelnikom, w jaki sposób mogli zabezpieczać się przed chorobami wenerycznymi. Zalecano nie odbywać stosunków z obcymi kobietami $\mathrm{i}$ „,okazującymi podejrzane oznaki chorobowe", jak na przykład: długotrwała chrypka, liczne zaczerwienienia na skórze, czy biało-szare plamy na ustach oraz języku. Za środki zapobiegawcze redakcja uznawała między innymi prezerwatywy, choć jak napisano nie w pełni zabezpieczały przed zarażaniem, gdyż często pękały ${ }^{22}$. Popierano wniosek pewnego adwokata z Drezna, by mężczyźni chcący wstąpić $\mathrm{w}$ związek małżeński zobowiązani zostali do przedkładania przyszłym teściom zaświadczenia lekarskiego, że nie są zarażeni chorobami płciowymi ${ }^{23}$. Twórcy miesięcznika radzili też redakcjom czasopism polskich, aby nie zamieszczały reklam: „,szarlatanów i hańbiących swój stan lekarzy, obiecujących wszelkie choroby płciowe i ich skutki wyleczyć w krótkim czasie, nawet piśmiennie - ani reklam dla tajnych leków przeciw tym chorobom zalecanych" ${ }^{24}$.

Redakcję miesięcznika niepokoił szerzący się rozwój chorób wenerycznych, do którego dochodziło zwłaszcza w wojsku. Potwierdzają to badania lekarza sztabowego ze Lwowa Stefana Burczyńskiego, który zalecał innym lekarzom wojskowym zajęcie się tym ważnym problemem. Po odbyciu służby lub w trakcie urlopów zarażeni chorobami intymnymi żołnierze rozprzestrzeniali je bowiem wśród swoich bliskich. Jak wykazały badania sanitarne, w armii austro-węgierskiej na schorzenia przenoszone drogą płciową zapadało rocznie około 18000 żołnierzy, czyli aż 60\% wszystkich zachorowań przypadało w wojsku na te dolegliwości. Najwięcej żołnierzy zarażonych było rzeżączką. Armia była więc "głównym rozsadnikiem chorób wenerycznych". Zalecano badać żołnierzy pod kątem tych przypadłości - i to nie tylko zwykłych szeregowych, ale również kadrę oficerską, a zatajanie chorób płciowych surowo karać. Chory żołnierz zobowiązany był do wskazania miejsca, gdzie mogło dojść do zarażenia. Zdaniem redakcji, pożądane byłoby wysyłanie przez szpitale cywilne do władz wojskowych wykazu pacjentów leczonych na choroby intymne, którzy zamierzali wstąpić do armii ${ }^{25}$.

${ }^{21}$ Drobiazgi. Wpływ chorób wenerycznych na ustrój nerwowy, "Świat Płciowy” 1906, luty, s. 48 .

22 Drobiazgi. Jak chronić się przed zakażeniem wenerycznym?, „Świat Płciowy” 1905, grudzień, s. 48; Ochrona od chorób wenerycznych, „Świat Płciowy" 1906, styczeń, s. 27-28.

${ }^{23}$ Drobiazgi. Świadectwa lekarskie oblubieńca, "Świat Płciowy” 1905, maj, s. 49.

${ }^{24}$ J. Bilewski, Walka z zaraza weneryczna, "Świat Płciowy" 1905, maj, s. 41.

${ }^{25}$ Dr. B. W., Syfilis i weneria w armii, "Świat Płciowy” 1905, październik, s. 29-32; Weneria w wojsku, „Świat Płciowy” 1905, grudzień, s. 11-13. 
Z prostytucją związane było inne niepożądane zjawisko społeczne, które niepokoiło twórców „Świata Płciowego”, czyli tak zwany handel żywym towarem. Proceder ten znany był na całym świecie. Ofiarami handlarzy padały głównie kobiety pochodzące z Niemiec, Austrii, Francji, Szwajcarii, Rosji, czy USA. Począwszy od połowy XIX wieku zaczęto go zwalczać na wielu płaszczyznach, w tym prawnej i instytucjonalnej ${ }^{26}$.

Charakteryzowany periodyk handel kobietami określił haniebną plagą ludzkości. Publicyści przestrzegali czytelników przed „łowcami młodych dziewcząt”, zwanych potocznie "kadetami”, grasującymi w Nowym Jorku oraz w innych portowych miastach Stanów Zjednoczonych. Procederem tym trudnili się młodzi, eleganccy mężczyźni, którzy potrafili zbałamucić naiwne dziewczęta, na przykład obietnicą małżeństwa, a nawet wstępowali z nimi w fikcyjne związki, a następnie wywozili do innych miast i sprzedawali właścicielom domów publicznych. Podobnie, zdaniem redakcji „Świata Płciowego”, było w Galicji, gdzie handlarze kobietami swe ofiary wywozili również do innych krajów, w tym do Indii, Egiptu, czy Turcji. Ostrzegano przed skorumpowaną lub często bezradną policją, która nie potrafiła poradzić sobie z tym procederem ${ }^{27}$. Informowano o powstaniu międzynarodowej „Ligi dla zwalczania handlu dziewczętami”, która miała swoje oddziały również w galicyjskich miastach, we Lwowie i Czerniowcach ${ }^{28}$. Naczelnym zadaniem tej organizacji było wykrywanie przestępstw handlarzy „,białymi niewolnicami” 29 .

Edukowano też czytelników w zakresie zaburzeń (dewiacji) seksualnych, zwanych wówczas zwyrodnieniami erotycznymi. Opisano na przykład głośny przypadek profesora uniwersytetu wiedeńskiego Teodora Boera, skazanego na trzy miesiące więzienia za pedofilię ${ }^{30}$. Do zaburzeń płciowych zaliczano ponadto: impotencję, homoseksualizm, onanizm i nekrofilię.

Homoseksualizm uznawano za jedną $\mathrm{z}$ najbardziej niebezpiecznych „form zwyrodnienia płciowego". Skłonności do niego bardziej wykazywali mężczyźni niż kobiety. Opisano jednak historię pewnego tajnego angielskiego stowarzyszenia kobiecego, znanego pod nazwą „Klub Safony”, zrzeszającego kobiety oddające się homoseksualizmowi, które nie widziały w swej „działalności” niczego złego. W wyniku obserwacji udało się dowieść, że homoseksualizmem dotknięte były najczęściej osoby, które "powstały ze złego materiału" genetycznego, głównie więc: potomstwo alkoholików, dzieci ro-

${ }^{26}$ J. Macko, Nierząd jako choroba społeczna, Warszawa 1938, s. 193; R. Antonów, Drogi hańby. Piśmiennictwo polskie przełomu XIX i XX wieku o handlu „żywym towarem”, Wrocław 2013, s. 13-14.

${ }^{27}$ H. Polańska, Handel dziewczętami, "Świat Płciowy” 1905, październik, s. 20; Drobiazgi. "Kadeci”, „Świat Płciowy” 1905, maj, s. 51; Drobiazgi. Handel dziewczętami, „Świat Płciowy” 1905, maj, s. 48.

28 Drobiazgi. Zwalczanie handlu dziewczętami, „Świat Płciowy” 1905, listopad, s. 51.

${ }^{29}$ H. Polańska, Handel dziewczętami, s. 20.

30 A. Wójcikiewicz, Z dziedziny zwyrodnień erotycznych, „Świat Płciowy” 1906, luty, s. 40. 
dziców chorujących na syfilis i neurastenię. Przy okazji omawiania zjawiska homoseksualizmu zwrócono uwagę czytelników pisma na dwie inne dewiacje erotyczne, czyli na oziębłość seksualną oraz seksoholizm ${ }^{31}$.

Kolejnym zaburzeniem seksualnym, o którym pisano był onanizm, szczególnie niebezpieczny u młodzieży. Zdaniem francuskiego lekarza badającego choroby weneryczne Philippe Ricorda (1800-1899), oddająca się samogwałtowi młodzież wolniej rosła. U kobiet mogło dojść do chorób macicy, nieregularnych menstruacji, bólów krzyża, a nawet skurczy żołądka ${ }^{32}$. Współpracownik „Świata Płciowego" Kazimierz Mielecki, powołując się na badania nad masturbacją prowadzone przez wiedeńską działaczkę ruchu kobiecego Emmę Eckstein (1865-1924), zwracał uwagę na uświadamianie dzieci odnośnie tych trudnych tematów. Zgadzał się z Eckstein, że najmłodsi najczęściej ulegali tej dewiacji pod wpływem rówieśników i służby domowej. Bardziej narażone na onanizm były dzieci miejskie niż wiejskie. Mielecki apelował więc do rodziców, aby zaufali dzieciom i nie wymierzali im surowych kar, gdyby okazało się, że ulegli tej dewiacji, lecz spokojnie tłumaczyli, że „nałóg (nie) jest zbrodnią", a jego wykrycie - tragedią ${ }^{33}$.

Kolejnym omawianym na łamach miesięcznika zwyrodnieniem była nekrofilia, czyli seksualny pociąg do zwłok. Przypadłość ta znana była już w starożytności i opisywana przez greckiego historyka Herodota z Halikarnasu. Byli nią wówczas dotknięci na przykład balsamujący zwłoki. Twórcy "Świata Płciowego" zastanawiali się, w czym tkwiła przyczyna tej dewiacji. Niektórzy uczeni uważali, że stanowiła odmianę sadyzmu; za tą teorią przemawiał fakt dość częstego bezczeszczenia zwłok po odbytym stosunku. Inni uważali, że osoby dotknięte tą potworną przypadłością są chore umysłowo. Byli jednak przeciwnicy tej teorii, głoszący, że cierpiący na nekrofilię zawsze działali z pełną celowością i świadomością ${ }^{34}$.

Zwracano też uwagę na impotencję kobiet i mężczyzn. Niemoc płciowa u kobiet mogła leżeć, zdaniem twórców miesięcznika, po stronie budowy anatomicznej, w tym przypadku wystarczał najczęściej drobny zabieg chirurgiczny i wszystko wracało do normy. Przyczyna impotencji u kobiet mogła też mieć związek z oziębłością seksualną ${ }^{35}$. U mężczyzn tkwiła w braku erekcji lub ejakulacji. Mogło mieć to związek z wrodzoną ułomnością fizyczną czy

31 T. OK., Próba wyttumaczenie homoseksualizmu, czyli zmysłowej miłości ku osobom ptci tej samej, „Świat Płciowy” 1906, styczeń, s. 10-14; Z dziedziny zwyrodnień erotycznych. Homoseksualizm, „Świat Płciowy" 1905, wrzesień, s. 30-33.

32 A. Roicki, Samogwatt u mężczyzn i kobiet, „Świat Płciowy” 1905, październik, s. 26-28.

33 K. Mielecki, Zwalczanie onanizmu, "Świat Płciowy” 1905, listopad, s. 30-33.

34 A. Seńkowski, Z dziedziny zwyrodnień erotycznych. Nekrofilizm, "Świat Płciowy” 1905, listopad, s. 34-39.

35 Dr. M. T-k, Impotencja u kobiet, „Świat Płciowy” 1905, grudzień, s. 27-28. 
onanizmem. Niektórzy upatrywali w tym następstw narkomanii, cukrzycy i chorób nerwowych ${ }^{36}$.

Sporo miejsca poświęcano kwestii małżeńskiej. Za jeden z warunków udanego małżeństwa uważana była miłość. Jak donosiła redakcja, we Francji zreformowano nawet kodeks cywilny, gdzie w artykule 212 znalazł się zapis: „Małżonkowie winni są sobie nawzajem miłość, wierność, pomoc i podporę". Brak miłości w małżeństwie przyrównywano do raka toczącego ówczesne społeczeństwo ${ }^{37}$. Donoszono też za dziennikiem „New York Herald”, że do zreformowania prawa małżeńskiego dążył prezydent USA Theodore Roosevelt. W tym kraju każdy stan miał bowiem odrębne przepisy w tej materii. Na przykład, trzynaście amerykańskich stanów w ogóle nie określało wieku dla osób wstępujących w związki małżeńskie, w dziewięciu było to 18 lat dla mężczyzn i 16 dla kobiet, w trzech - odpowiednio - 21 i 18, w jednym - 14 i 13, w czterech - 14 i 12 lat $^{38}$. Działaczki feministyczne z Zurychu uważały, że najlepszym wiekiem dla przyszłej mężatki było ukończone 20 lat. Ich zdaniem, zbyt młode mężatki podatniejsze były na anemię, choroby płucne oraz przedwczesne starzenie się $e^{39}$.

Redakcja „Świata Płciowego” krytykowała prawo panujące w Indiach, które pozwalało na wstępowanie w związki małżeńskie dzieciom mającym 5, a nawet i mniej lat. Ten małżeński zwyczaj wypływał z postanowień religijnych. Niezamężna dziewczynka w wieku 10-12 lat zaliczana była do kasty służebnic, na jej ojcu spoczywał ciężki grzech, a w niektórych częściach tego kraju uważany był nawet za dzieciobójcę. Oczywiście, pomiędzy ceremonią zaślubin a faktycznym pożyciem małżeńskim upływało sporo czasu. Zwolennicy tego prawa uważali, że tak przedwczesne małżeństwa stanowiły dla chłopców „skuteczną prezerwatywę przeciw seksualnym wykroczeniom" 40.

Za szalone małżeństwo twórcy periodyku uznali zaślubiny z miłości, do jakich doszło w Genewie. Pewien młody Niemiec poślubił tam 18-letnią dziewczynę, kalekę bez górnych i dolnych kończyn, którą poznał w cyrku, gdzie wystawiano ją na widok publiczny. Małżeństwu ostro sprzeciwił się właściciel cyrku, gdyż stracił główną atrakcję i dochód. Zastanawiano się jednak nad sensownością takiego małżeństwa i radzono, aby w podobnych przypadkach nie zezwalały na to władze miejskie czy duchowne ${ }^{41}$.

Z małżeństwem dość ściśle związana jest rozrodczość. Publicyści „Świata Płciowego" uważali, że w małżeństwach nie posiadających potomstwa po

\footnotetext{
36 Dr. H. Sch., O impotencji u mężczyzn i jej przyczynach, „Świat Płciowy” 1906, luty, s. 11-13.

37 H. Polańska, Miłość, jako ustawowy warunek matżeństwa, "Świat Płciowy” 1905, maj, s. 23-25.

38 Drobiazgi. Małżeństwa amerykańskie, „Świat Płciowy” 1905, maj, s. 46-47.

39 Drobiazgi. Kiedy powinny dziewczęta wychodzić za mąż?, „Świat Płciowy” 1905, wrzesień,

40 Drobiazgi. Małżeństwo indyjskich dzieci, „Świat Płciowy” 1906, luty, s. 45-46.

41 Drobiazgi. Szalone mał̇̇eństwo, „Świat Płciowy” 1906, luty, s. 47-48.
} s. 52 . 
kilku latach pożycia zanika więź, a bycie $\mathrm{w}$ takim związku staje się pełne wzajemnej niechęci, wyrzutów i oskarżania się. W małżeństwach obarczonych zaś zbyt licznym potomstwem zaciera się życie indywidualne rodziców, całkowicie podporządkowane dzieciom. Donoszono czytelnikom, że w każdym człowieku drzemie instynkt rozrodczy, a miłość tylko go rozbudza. Rodzicielstwa wyrzekali się jedynie ludzie bardzo praktyczni, czyli tak zwane sobkowskie indywidua ${ }^{42}$.

Zwracano też uwagę na kwestię niepłodności, która stawała się przyczyną problemów nawet w najlepszych związkach. Bezpłodność mogła być wynikiem wadliwej budowy anatomicznej narządów płciowych zarówno kobiet, jak i mężczyzn. Ówczesna medycyna lepiej radziła sobie z bezpłodnością żeńską, na co wpływ miały też stany zapalne organów rozrodczych czy anemia. Uważano, że $\mathrm{w}$ tym przypadku możliwe jest sztuczne zapłodnienie. Informowano czytelników, że jako pierwszy próbę sztucznego zapłodnienia zastosował na zwierzętach w 1776 roku włoski uczony Spallanzani, a Anglik J. Hunter podobnego zabiegu próbował dokonać już w 1793 roku na kobiecie ${ }^{43}$.

Zdarzało się, że małżeństwa obarczone zbyt licznym potomstwem decydowały się na aborcję, choć częściej dokonywały jej kobiety samotne, czy porzucone przez mężczyzn. Redakcję nurtował problem, czy aborcja jest zbrodnią i jakiej karze powinna podlegać. Informowano czytelników, że już na początku średniowiecza zabieg ten uchodził za ,jedno z najpotworniejszych wykroczeń" i podlegał surowej karze. Powoływano się na ówcześnie obowiązujący niemiecki kodeks karny, który w paragrafie 218 czyn taki uznawał za karygodny i tylko przy "łagodzących okolicznościach karę do minimum 6 tygodni więzienia obniża". Przeciwko surowości niemieckiego prawa aborcyjnego wystąpiła w 1904 roku, w broszurze swego autorstwa zatytułowanej Das Weib am Ende des Jahrhunderts, działaczka feministyczna hr. Gisela Streitberg. Dziełko nazwano ryzykownym i nad wyraz zuchwałym. Opinię publiczną oburzał zwłaszcza fakt, że przeciwko surowemu prawu aborcyjnemu wystąpiła po raz pierwszy kobieta. Redakcja "Świata Płciowego" biorąc autorkę w obronę, napisała, że: „Wywody jej są utrzymane w tonie poważnym, ściśle naukowym i opierają się na (...) przykładach z życia realnego wziętych" ${ }^{\prime 4}$.

Nie wszystkie małżeństwa były udane, niektóre kończyły się separacją, a inne rozwodem. Za jedną z przyczyn takiego stanu rzeczy uważano postawę ówczesnych małżonków, którzy nie potrafili żyć dla rodziny i siebie nawzajem. Dużo czasu pochłaniało im na przykład utrzymywanie

${ }^{42}$ A. Kalnicki, Problem płodności, „Świat Płciowy” 1905, październik, s. 5-10.

${ }^{43}$ Dr. B. W., Zapłodnienie sztuczne, "Świat Płciowy” 1905, listopad, s. 22-23; M. Ciszek, Sztuczne zaptodnienie z perspektywy bioetyki rodziny, Studia Ecologiae et Bioethicae, 2006, 4, s. 160.

${ }^{44}$ Drobiazgi. Czy usunięcie ptodu jest zbrodnią?, „Świat Płciowy” 1905, maj, s. 49. 
poprawnych stosunków towarzyskich, czy działalność społeczna. Redakcja miesięcznika informowała o powstaniu w 1904 roku w Wiedniu Stowarzyszenia Separowanych Małżonków Katolickich, które już po niecałym roku działalności liczyło kilka tysięcy członków. Wielu sympatyków miała ta organizacja w Czechach, a zainteresowaniem cieszyła się nawet w Hiszpanii. Stowarzyszenie walczyło $\mathrm{z}$ obowiązującą $\mathrm{w}$ monarchii austro-węgierskiej ustawą, uznającą zgodnie z przepisami kościelnymi nierozerwalność związku nawet w przypadku, gdy tylko jedno z małżonków było wyznania katolickiego ${ }^{45}$.

Jak wykazały prowadzone na Węgrzech statystyki, najczęstszymi przyczynami rozwodów były między innymi: niewierność, wiarołomstwo, niemoralne prowadzenie się jednego z małżonków, bezpłodność. Po rozwodach dzieci w większości przypadków pozostawały przy matkach ${ }^{46}$. Redakcja informowała ponadto czytelników o obowiązującym w amerykańskim stanie Illinois prawie, według którego osoby rozwiedzione mogły oficjalnie wstępować w nowe związki dopiero po upływie roku ${ }^{47}$.

Periodyk prowadził też akcję uświadamiania dzieci i młodzieży na tematy seksualne. Pisano, że sprawą tą zajęło się między innymi Towarzystwo Nauczycieli z Berlina, wydając stosowne uchwały. Nie zalecało ono wprawdzie prowadzenia akcji uświadamiającej wśród uczniów szkół ludowych, ale gdyby jednak nauczyciele dostrzegli problem onanizmu, powinni przeprowadzać indywidualne rozmowy z uczniami dotkniętymi tym problemem. Jeżeli nauczyciel nie potrafił takiej rozmowy, na przykład z braku wiedzy, przeprowadzić, to nie powinien się do niej zmuszać, tylko poprosić o pomoc bardziej zorientowanego w temacie kolegę. Radzono, aby z uczniami szkół ludowych odnośnie problemów płciowości rozmawiali ich rodzice, których wcześniej nauczyciele powinni odpowiednio przygotowaćt8.

Za możliwie wczesnym uświadamianiem przez rodziców młodego pokolenia w kwestiach seksualnych wypowiadał się uczony z Berlina Friedjung. Jego zdaniem, powinni „upatrzyć stosowną chwilę i dobrotliwie, z rodzicielską powagą a przyjacielską serdecznością wyjaśniać tajemnice popędu reprodukcyjnego". Posłużyć się przy tym mogli przykładami ze świata roślinnego ${ }^{49}$.

Problemem uświadamiania płciowego zainteresowało się Towarzystwo Krzewienia Zdrowia w Wiedniu, którego członkowie byli zdania, że zająć się tym powinni rodzice, a szkoła dopiero w późniejszym etapie kształcenia (gimnazjalnym). Postulowano wprowadzenie w ostatnich klasach szkół

\footnotetext{
${ }^{45}$ W sprawie reformy małżenstwa, „Świat Płciowy” 1905, wrzesień, s. 26-29.

46 J. Łabędzki, Rozwody na Wegrzech, „Świat Płciowy” 1905, maj, s. 26-27.

47 Drobiazgi. 30.000 rozwódek, „Świat Płciowy” 1905, wrzesień, s. 52.

48 T. Okończyc, Uświadamianie młodzieży o życiu płciowym, „Świat Płciowy” 1905, maj, s. 9.

49 Tamże, s. 9-10.
} 
średnich osobnego przedmiotu nauczania pod nazwą somatologia i higiena, a wykładać go powinni lekarze szkolni ${ }^{50}$.

Niektórzy polscy pedagodzy byli podobnego zdania uważając, że obszerniej na tematy płciowości wypowiadać się powinni nauczyciele dopiero w ostatniej klasie szkoły wydziałowej, na przykład podczas zajęć z przyrody, historii powszechnej, religii, czy literatury. Na tematy seksualne można było także edukować młodzież kończącą gimnazjum bądź seminarium nauczycielskie. Nauczyciel prowadzący z młodzieżą pogadanki na temat życia seksualnego powinien być człowiekiem szlachetnym, rozumiejącym potrzeby wychowanków, ich prawdziwym przyjacielem i powiernikiem. W szkołach męskich mógł wziąć to na siebie lekarz szkolny. Uświadamianiem dorastających dziewcząt winny zając się ich matki, ale nie zawsze uważały się one za osoby kompetentne w tym zakresie ${ }^{51}$. Doświadczeni nauczyciele radzili, aby osoby, które podjęły się kwestii pouczania młodzieży w sprawach płciowych podchodziły do tego tematu niezwykle poważnie, gdyż przybrać ono mogło niepożądane skutki:

(...) zawsze wywoła burzę uczuć w młodej duszy, wstrząśnie nerwami młodego organizmu. Dla jednych otwiera świat, pełen powabu zmysłowego - w drugim obudza wstręt. Słyszy się nieraz o panienkach inteligentnych, które uświadomione prawdą, może w sposób niewłaściwy, nabrały takiego wstrętu do małżeństwa, że odrzuciły starających się, a miłych im nawet poprzednio konkurentów. Słyszy się też i o mężatkach, które nieświadomość przypłaciły chorobą nerwową. Ostrożnie więc, ostrożnie $\mathrm{z}$ uświadamianiem! ${ }^{52}$

Pomna nauczycielskich przestróg redakcja „Świata Płciowego" wystosowała ankietę do młodzieży. Pytano między innymi, przez kogo, kiedy i w jakich okolicznościach doszło do uświadomienia w kwestiach seksualnych i jakie wywarło ono skutki, oraz jak młodzi zamierzają w przyszłości postępować $\mathrm{w}$ tym względzie $\mathrm{z}$ własnymi dziećmi ${ }^{53}$.

Ankieta zamiast pobudzić młodzież do dyskusji, wywołała dyskusję wśród rodziców. Jeden z listów do redakcji wystosował ojciec 15-letniego syna, który jak sam się określił był człowiekiem "starej daty”. Uważał sprawę edukacji seksualnej za niepotrzebną i nie wymagającą dyskusji, a młodzież, gdy przyjdzie potrzeba, sama dowie się, tak jak on dowiedział się mając 28 lat. Za najlepszy środek wychowawczy uważał domową dyscyplinę, a resztę pozostawiał "Opatrzności, która wie co robi" ${ }^{54}$.

${ }^{50}$ Drobiazgi. Sprawa uświadamiania płciowego, „Świat Płciowy” 1906, styczeń, s. 47.

51 Tamże, s. 10-11.

${ }^{52}$ Tamże, s. 11-12.

53 Tamże, s. 13.

${ }^{54}$ Czy i kiedy uświadamiać młodzież o życiu ptciowym? (Głosy rodziców), „Świat Płciowy” 1905, grudzień, s. 39-40. 
Kolejny ojciec był zdania, że uświadamianie mogło ochronić dzieci przed chorobami wenerycznymi. Dlatego radził, aby rodzice na kwestie te zaczęli zwracać uwagę, kiedy ich dzieci mają po 12-14 lat. On sam bez niepotrzebnych dyskusji zwrócił uwagę synowi na onanizm, a potem wywiązała się między nimi rozmowa na temat popędu płciowego ${ }^{55}$.

Matki piszące $\mathrm{w}$ tej sprawie do redakcji uważały, że należy uświadamiać dzieci w sprawach erotyki, ale przeprowadzając z nastoletnimi córkami stosowne rozmowy czuły się zakłopotane, a nawet zawstydzone, zwłaszcza gdy same wychowywane były „w cnocie i czystości”. Jedna z matek pisała, że choć nie poruszała z córkami tych kwestii, te „bardzo wcześnie dowiedziały się (...) jak rzecz się ma", a potem same dopytywały się stawiając ją w kłopotliwej sytuacji. Jej zdaniem, to nauczyciele i duchowni powinni zająć się edukacją seksualną młodzieży ${ }^{56}$.

Współpracujący z miesięcznikiem Leopold Bronisław Wołowicz przed przystąpieniem do edukowania seksualnego radził zapoznać się $\mathrm{z}$ dwiema pracami. Jedną z nich była książka znanej publicystki, działaczki społeczno-oświatowej i politycznej, rzeczniczki emancypacji kobiet Izabeli Moszczeńskiej (1864-1941) Co każda matka swojej dorastającej córce powiedzieć powinna. Dziełko ukazało się w Warszawie w 1904 roku nakładem oraz drukiem Michała Arcta i liczyło 100 stron. Odnotowała je również konkurencyjna "Czystość" ${ }^{57}$. Kolejną polecaną przez Wołowicza pracą była, licząca 242 strony, książka niemieckiego uczonego Rudolfa Penziga (1855-1931) Jak odpowiadać na pytania dziecięce (Warszawa 1905) ${ }^{58}$.

Uwadze twórcom miesięcznika nie umknął fakt założenia w Berlinie w 1905 roku Związku Ludowego ku Zwalczaniu Nieobyczajności w Mowie i Piśmie, którego prezesem został Otton Leixner von Grünberg (1847-1907), historyk, dziennikarz, pisarz i krytyk literacki. Członkowie tej organizacji postanowili zająć się kwestią pornografii wśród niemieckiej młodzieży męskiej w wieku 12-15 lat. Chłopcy kupowali zagraniczną literaturę pornograficzną, a w Berlinie wykryto księgarnię zajmującą się sprzedażą tego rodzaju publikacji. Związek przyjął zasadę, że odrodzenie moralne młodzieży nastąpić mogło poprzez uprawianie sportu, wpajanie poczucia samodzielności i dążenia do szlachetnych celów. Starał się ułatwiać młodzieży obojga płci godziwego obcowania ze sobą. Posiadał liczne oddziały funkcjonujące na terenie Rzeszy, między innymi

55 Tamże, s. 41-42.

56 Tamże, s. 42-43.

57 L.B. Wołowicz, Estetyka i moralność a uświadamianie młodzieży, „Świat Płciowy” 1905, listopad, s. 21; J. Rzepecki, Moszczeńska (Moszczeńska-Rzepecka) Iza (Izabela), [w:] Polski Stownik Biograficzny, t. 22, Wrocław - Warszawa - Kraków 1977, s. 80.

58 L.B. Wołowicz, Estetyka, s. 21. 
w: Berlinie, Wrocławiu, Legnicy, Lipsku, Hanowerze, Magdeburgu, czy Królewcu. Wydawał własny organ prasowy „Korespondenzblatt” 59 .

Zainteresowaniem pisma cieszyło się również galicyjskie Towarzystwo "Ochrona Młodzieży", którego zadaniem było zwalczanie alkoholizmu i zapobieganie rozwiązłości płciowej wśród młodzieży, na przykład poprzez zwalczanie wśród niej pornografii, otaczanie opieką podczas publicznych zabaw i zakaz wstępu nastoletnim chłopcom do domów publicznych ${ }^{60}$. Należy dodać, że lekarz, publicysta, pedagog, malarz i rzeźbiarz Henryk Kunzek (1871-1928) ${ }^{61}$ został pierwszym prezesem zarządu głównego tego Towarzystwa.

Edukacja seksualna polega na zdrowym rozwoju seksualnym, braku zaburzeń seksualnych i satysfakcji wynikającej ze współżycia płciowego. Jej nadrzędnym celem jest ukształtowanie człowieka zdrowego seksualnie, akceptującego swoją płeć, bez lęku i obaw wyrażającego seksualność w aspekcie fizycznym i psychicznym. Edukację seksualną należy zawsze dostosowywać do wieku. Powinna być wszechstronna i odnosić się do płciowości człowieka, zdrowia seksualnego i reprodukcyjnego oraz zachowań seksualnych. Tylko tak pojmowana wyposaży, często bardzo młodego, człowieka $\mathrm{w}$ umiejętności życiowe, przydatne do podejmowania prawidłowych decyzji w sferze seksualności ${ }^{62}$.

Podobnie na kwestie seksualności zapatrywali się twórcy omawianego periodyku ukazującego się przeszło 100 lat temu. Dlatego nader często spotykali się z niezrozumieniem, lękiem oraz kpiną opinii społecznej, a zwłaszcza lekarzy i duchownych. Nie należy się zatem dziwić, że duża część konserwatywnych czytelników, którzy choć raz zetknęli ze "Światem Płciowym” uważali je za pismo pornograficzne, zachęcające do aktywności seksualnej, opowiadające się za wolną miłością, aborcją, biorące w obronę prostytutki, a nawet dewiantów seksualnych.

\section{BIBLIOGRAFIA}

\section{Prasa}

„Czystość" 1905-1906.

"Lwowski Tygodnik Lekarski” 1911.

"Świat Płciowy" 1905-1906.

${ }^{59}$ Drobiazgi. Zwiazek ku zwalczaniu nieobyczajności, „Świat Płciowy” 1905, maj, s. 47-48.

${ }^{60}$ Drobiazgi. Tow.[arzystwo] "Ochrona młodzieży”, "Świat Płciowy” 1905, grudzień s. 47; I. Sprawozdanie Wydz.[iału] Tow.[arzystwa] "Ochrona młodzieży” za czas od 29 czerwca 1904 do 31 października 1905. (Streszczenie), „Czystość” 1905, nr 11, s. 118-120.

${ }^{61}$ Drobiazgi. Tow.[arzystwo]..., s. 47; I. Huml, Kunzek Henryk, [w:] Polski Stownik Biograficzny, t. 16, Wrocław - Warszawa - Kraków 1971, s. 210.

${ }_{62}$ U. Walczak, Edukacja seksualna jako forma wspierająca rozwój psychoseksualny dzieci w wieku wczesnoszkolnym, Zeszyty Naukowe PUNO, 2017, 5, s. 121-122. 


\section{Opracowania}

Antonów R., Drogi hańby. Piśmiennictwo polskie przełomu XIX $i$ XX wieku o handlu „żywym towarem", Wydział Prawa, Administracji i Ekonomii Uniwersytetu Wrocławskiego, Wrocław 2013.

Babik M., Polskie koncepcje wychowania seksualnego w latach 1900-1939, Wyższa Szkoła Filozoficzno-Pedagogiczna „Ignatianum”: Wydawnictwo WAM, Kraków 2010.

Baczkowski M., Prostytucja w Krakowie na przetomie XIX i XX w., Studia Historyczne, 2000, 4.

Bołdyrew A., Społeczne inicjatywy na rzecz walki z patologiami w Królestwie Polskim na przełomie XIX i XX wieku, Studia Gdańskie, 2012, 31.

Bołdyrew A., Społeczeństwo Królestwa Polskiego wobec patologii społecznych w latach 18641914, Wydawnictwo Uniwersytetu Łódzkiego, Łódź 2016.

Ciszek M., Sztuczne zapłodnienie z perspektywy bioetyki rodziny, Studia Ecologiae et Bioethicae, 2006, 4 .

Czym jest edukacja zdrowotna?, http://edukacja.pomocnie.com.pl/czym-jest-edukacja-zdrowotna/, [dostęp: 02.11.2016].

Franke J., "Czystość" (1905-1909) Augustyna Wróblewskiego albo iluzja etycznej krucjaty, Wydawnictwa Uniwersytetu Warszawskiego, Warszawa 2013.

Gołdyn P., Pogarda dla zawodu, litość dla człowieka. Społeczno-edukacyjne formy działalności wobec kobiet zagrożonych prostytucja w Polsce (1918-1939), Kaliskie Towarzystwo Przyjaciół Nauk, Kalisz 2013.

Huml I., Kunzek Henryk, [w:] Polski Stownik Biograficzny, t. 16, Zakład Narodowy im. Ossolińskich: Wydawnictwo Polskiej Akademii Nauk, Wrocław - Warszawa - Kraków 1971.

Jarowiecki J., Prasa lwowska w latach 1864-1918. Bibliografia, Wydawnictwo Naukowe Akademii Pedagogicznej, Kraków 2002.

Kośmiński S., Słownik lekarzów polskich, Nakł. autora: skład gł. w Księgarni Gebethnera i Wolffa, Warszawa 1888.

Krasińska I., Edukacja zdrowotna żeńskiej stużby domowej na łamach "Przyjaciela Stug” (18971918) (w druku).

Krawczyńska M., Kuplerka, sutener i stręczycielstwo. Regulacja polskiego prawa, Prawo i Płeć, 2006, 8.

Lisak A., Miłość, kobieta i małżeństwo w XIX wieku, Bellona, Warszawa 2009.

Macko J., Nierzą jako choroba społeczna, Nakł. Polskiego Komitetu Walki z Handlem Kobietami i Dziećmi, Warszawa 1938.

Rzepecki J., Moszczeńska (Moszczeńska-Rzepecka) Iza (Izabela), [w:] Polski Stownik Biograficzny, t. 22, Zakład Narodowy im. Ossolińskich: Wydawnictwo Polskiej Akademii Nauk, Wrocław - Warszawa - Kraków 1977.

Sikorska-Kulesza J., Zło tolerowane. Prostytucja w Królestwie Polskim w XIX wieku, Wydawnictwo Mada, Warszawa 2004.

Walczak U., Edukacja seksualna jako forma wspierająca rozwój psychoseksualny dzieci w wieku wczesnoszkolnym, Zeszyty Naukowe PUNO, 2017, 5.

Woynarowska B., Edukacja zdrowotna. Podręcznik akademicki, Wydawnictwo Naukowe PWN, Warszawa 2013. 